except for two cases in which the spheres had been placed incorrectly in relation to the pineal body. Partial necrosis of the pineal body (50-80 per cent) was obtained in a few cases in which the position of the spheres apparently had not been optimal in relation to the pineal body. However, since a total of eight cases out of 11 surviving cases were obtained with a complete destruction of the pineal body, it was concluded that the method described must be considered as a suitable means for localized destruction of the pineal body, and other small tissue areas as well.

This work was supported in part by the Tullberg Fund, University of Uppsala. We acknowledge the advice of Prof. M. D. Altschule, McLean's Hospital, Waverley, Mass., in preparing the manuscript.

UNO HoLMGREN

Zoological Institute,

University of Uppsala.

Karolinska Institute,

University of Stockholm.

1 Exner, A., and Boerse, J., Deut. Z. Chir., 107, 182 (1910).

'Kitay, J. I., and Altschule, M. D., The Pineal Gland. A Review of the Physiological Literature (Harrard Univ. Press, 1954).

s Notter, G., Acta Radiol., Stockholm, Supp., 184, 1 (1959).

- Ginell, W. S., and Simon, G. P., Nucleonics, 11, 49 (1953).

${ }^{5}$ Ginell, W. S., and Doering, R., Preparation of Fused Clay Radiation Sources. I. Yttrium Macrospheres. Brookhaven Nat. Lab., Assoc.

- Notter, G., and Walinder, G., Strahlentherapie, 110, 95 (1959).

\section{A Biennial Copepod from Lake Hazen, Ellesmere Island}

SEveral species of copepods in the Arctic are known to have annual life-cycles in the sea ${ }^{1}$ and freshwater $^{2}$, and macroplanktonic Crustacea of northern seas may not breed until two years old ${ }^{3}$. So far as I am aware, no copepod has been described with a life-cycle greater than one year, and the extreme response of Cyclops scutifer in Lake Hazen to conditions of low temperature and limited food seems worth recording.

Lake Hazen (lat. $81^{\circ} 45^{\prime} \mathrm{N}$., long. $71^{\circ} 00^{\prime} \mathrm{W}$.) is the largest lake of the Queen Elizabeth Islands of high-arctic Canada. It is glacier-fed, cold and deep, and is not always entirely free from ice in summer. Primary productivity is very low, and the fauna is small in species and individuals.

The zooplankton was sampled regularly between mid-June and mid-August. The proportions of naupliar and copepodite stages at one offshore station on four successive dates are given in Fig. 1. The proportions of the stages were very similar in plankton collections from other parts of the Lake. The conspicuous and persistent bimodality of the population throughout the short sampling period can only be the result of a basically biennial life-history. A very few adults were taken in a surface haul on August 11, the last date of sampling, but presumably most copepodites do not reach adult-hood and breed until the autumn months. The products of this breeding pass the winter as nauplii and just begin to enter the copepodite stages by the following summer. The possibility of slight exchange between the generations is suggested by the stage I copepodites of June 18 and the stage II copepodites of August 11.

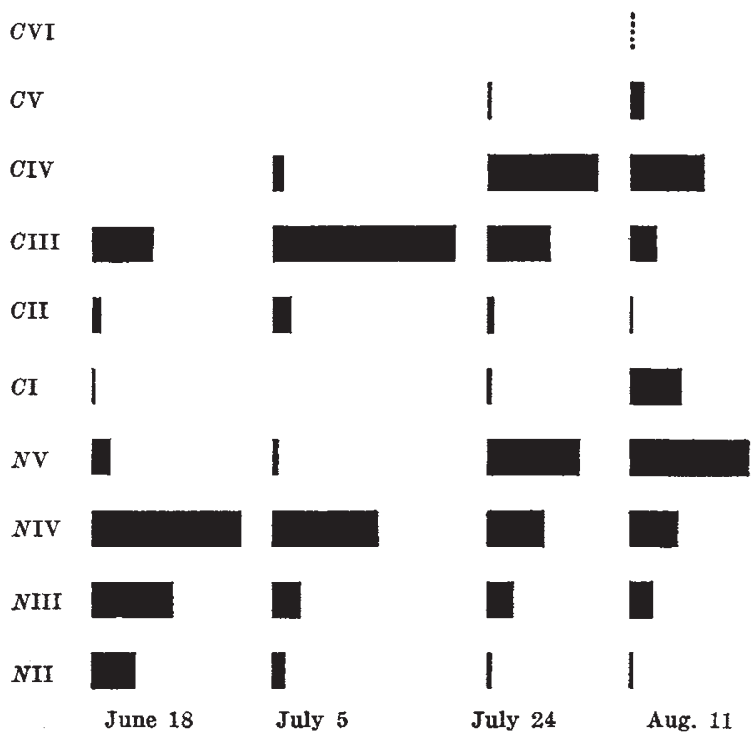

Fig. 1. The proportions of the stages of nauplii and copepodites of Cyclops scutifer in vertical plankton hauls from $32 \mathrm{~m}$. at the same station on four successive dates. No adults ( $C \mathrm{VII}$ ) taken in the vertical haul of August 11, but a few were taken in a nearby surface collection on that date

I am indebted to Dr. Edward B. Reed, Colorado State University, for finding the half-dozen adult copepods in the entire collection and identifying the species as Cyclops scutifer Sars. Field work was carried out in summer 1958 on the Canadian International Geophysical Year expedition to Ellesmere Island, organized by the Defence Research Board of Canada. Collections were analysed at the Bingham Oceanographic Laboratory, Yale University. A more complete account of the aquatic biology of Lake Hazen is in preparation.

\section{A. McLaren}

Arctic Unit,

Fisheries Research Board of Canada, 505 Pine Avenue West, Montreal 18.

1 Digby, P. S. B., J. Animal Ecol., 23, 298 (1954).

2 Comita, G. W., Ecology, 37, 576 (1956).

3 Dunbar, M. J., Canad. J. Zool., 85, 797 (1957).

\section{BACTERIOLOGY}

\section{Biosynthesis of Acetoin by Leuconostoc citrovorum}

Ir has been shown ${ }^{1}$ that in most bacterial cells acetoin is formed by the condensation of pyruvate and activated acetaldehyde. The findings of Beckhorn ${ }^{2}, \mathrm{De} \mathrm{Man}^{3}$ and Mizuno and Jezeski leave no doubt that in the heterofermentative genus Leuconostoc the synthesis occurs via acetolactate. It is still uncertain, however, if acetoin is formed from sugar and, if so, out of which part of the carbon chain of the sugar. Preliminary experiments showed that washed cell suspensions of Leuconostoc citrovorum ATCC 8082 do not form acetoin during glucose fermentation in a phosphate buffer. On the other hand, a large amount of acetoin is produced from pyruvate. When pyruvate and glucose are added simultaneously, the synthesis of acetoin is inhibited. 